Снежана У. Гудурић*

Драгољуб М. Петровић

Универзитет у Новом Саду

Филозофски факултет

https://doi.org/10.18485/ai_fonefonosj.2020.ch7

811.163.4'282(497.11 Драгачево)

\title{
РЕФЛЕКСИ ДУГОГ ЈАТА У ГОВОРУ ДРАГАЧЕВА.
}

Акустичка анализа. ${ }^{* *}$

У раду се испитује проблем рефлексације дугог јата у говору Драгачева, у случајевима када су аутори Речника драгачевског говора различито перципирали истоветне гласовне низове. Један од аутора је енергично оспорио раније записе о двосложном изговору рефлекса дугог јата у примерима типа виіек, бриіег, диंете, млијеко и сл. тврдећи да је у обама типовима примера рефлекс тог старога гласа једносложан, тј. вјек, брјег, дјете, млјеко. Акустичка анализа спорних лексема показала је недвосмислено присуство артикулације [i] испред [je], чија дужина варира од 34 до 118 милисекунди. Један од аутора Речни$\kappa a$ није перципирао ниједно [i] чије је трајање било испод 70 милисекунди, односно такве рефлексе дугог јата бележио је као једносложне [je]. У раду се нуде решења за испис спорних лексема у Речнику.

Кључне речи: дијалектологија, акустичка анализа, рефлекс јата, говор Драгачева

* snezana.guduric@ff.uns.ac.rs

** Овај рад урађен је у оквиру пројекта бр. 178002 Језици и културе y времену и простору који је финансирало Министарство просвете, науке и технолошког развоја Републике Србије. 


\section{1. Увод или : Да ли су Драгачевци - (и)јекавци?}

Драгачево се, записао је његов пасионирани истраживач, „угњездило између Шумадије и Старог Влаха” и чине га две варошице (Гуча и Лучани) и четрдесет осам села [Стојић 1996], при чему својом северном границом допире до Западне Мораве у околини Чачка, на западу се наслања на моравички, а на југу на студенички крај док га на североистоку и истоку падине Јелице одвајају од доњег Поибарја, у коме се ијекавштина, негде у близини Краљева, додирује с екавштином и одатле окреће према северозападу и преко Ваљевских планина избија на Дрину код Лознице.

Већ летимичан увид у литературу о Драгачеву показује да је то прилично темељито истражен део српскога етничког простора и о томе ћемо поменути тек неке најкрупније појединости.

Расправом о антропогеографским карактеристикама Доњег Драгачева отворена је велика Академијина (и Цвијићева) серија Насеља српских земаља (Ердељановић 1902), а после неколико година прикључила јој се и она о Горњем Драгачеву (Јовановић 1908); новије етнографске прилоге (Мирка Барјактаревића о Гучи и Радована Маринковића о Горачићима и Брезовици) међу корице исте књиге, заједно с Ердељановићевом и Јовановићевом, ставио је Борисав Челиковић додајући им и свој текст о драгачевским селима која нису обрађена у Насељима српских земаља („на основу објављених истраживања Јовише М. Славковића, Илије Мисаиловића и Драгољуба В. Корићанца") (Челиковић 2010)ㄹ․

1 Обрађено је 47 насеља Драгачева од којих општини Лучани припадају 34: Бели Камен, Вича, Властељица, Вучковица, Горачићи, Горња и Доња Краварица, Горњи и Доњи Дубац, Граб, Губеревци, Гуча, Дљин, Дучаловићи, Ђераћ, Живица, Зеоке, Каона, Кривача, Котража, Крстац, Лис, Лисице, Лучани, Марковица, 
„Записе на камену” о драгачевској прошлости саб(и)рали су многи истраживачи (Стојић 1986; Маринковић 2017; Николић 2007; Николић 2018), а богата, разноврсна и, понекад, необична сведочења о Драгачевциима записује Милоје Стевановић у више својих књига, од којих је једна послужила као основа за припрему Речника драгачевскога говора (Стевановић 2012), при чему се упориште за тај посао нашло и у монографском опису говора Драгачева (Ђукановић 1995), у коме су осветљени основни нивои његове структуре.

Кад су послови на изради тога речника далеко одмакли, Стевановић је енергично оспорио Ђукановићеве записе о двосложном изговору рефлекса дугог јата у примерима типа вијек, на лиіевој нози, сниіег, тијесто, бриіег, диंете Вјд, као и диंете Нјд, свиंећа, звијезда, на бриіегу и сл. тврдећи да је у обама типовима примера рефлекс тог старога гласа једносложан, тј. вјек, тјесто, брјег, ождрјебити, на брјегу, лјек, облјепити и сл. Као доказ за своје тврдње Стевановић наводи преко 2000 епитафа, записаних прича и народних мудрости (са навођењем казивача), на стотине изворних песама, аутентичних записа и рукописа писмених драгачевских сељака, а позива се и на Историјски архив који поседује богату грађу у коју се може извршити увид. Према његовим наводима, у Драгачеву се говори углавном екавски и нешто мало јекавски (дјете, бјели свјет, пјесма, који се код многих говорника јављају и у екавском облику: дете, бели свет, песма) док о ијекавском нема ни помена.

Милатовићи, Негришори, Пухово, Пшаник, Рогача, Ртари, Рти, Тијање и Турица; општини Ариље - 5: Вирово, Драгојевац, Миросаљци, Трешњевица и Церова; општини Ивањица - 3: Лиса, Луке и Осоница; граду Краљеву - једна: Толишница и граду Чачку - једна: Брезовице. У прилогу су објављене две карте Драгачева: Драгачево (1902) и Горње Драгачево (1908), као и карте драгачевских села и фотографије. 
Већина српских дијалектолога (између осталих П. Ивић, Д. Петровић, П. Ђукановић и др.) не деле ово мишљење и то најмање из два разлога. Један је од њих формалан: Драгачево, у целини, припада (и)јекавском појасу српскога дијалекатског простора и не може се тврдити да јекавизма има „нешто мало”, а да о ијекавизмy „нема ни помена”, посебно због тога што се јекавизам и ијекавизам посматрају као прости синоними (супротстављени, рецимо, екавизму и/ли икавизму). Уз екавске ликове, који су неспорно последица уравнавања према приликама у екавском изразу стандарднога српског језика (брег, реч, тепо ивеће, ређа се, ретко, стрельа; време, среда, ирева, стрељьали, погрешио и сл.), ипак су неспорни

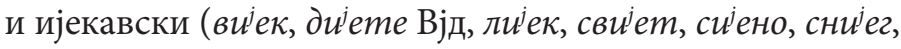
ивв $\kappa a$, вијенаи, лијечити, дијелили, смијенићеш (Букановић 1995: 35-41). Стевановићево истрајавање на тврдњи да таквих облика у драгачевском говору нема довели су до тога да се експериментална фонетика „призове да пресуди" у спору о коме је реч.

Овде се излажу главни налази те „пресуде”.

\section{2. Експериментална фонетика између биофизике, психоакустике и перцепције}

Шта се заправо тражило од експерименталне фонетике? На првом месту да покаже да ли се испред гласа [j] у склопу [je] на местима где је некада било дуго jam појављује и артикулација [i] или се у таквим случајевима глас $/ \mathrm{j} /$ непосредно артикулише иза сугласника (бјело, млјеко, лјеп, бјело и сл.). Друго, много важније питање за испис одредница у самом речнику, није било отворено постављено, али је заправо било суштинско у 
спору који је настао - да ли је дуго јат дало двосложни или једносложни рефлекс? Ово се питање заправо није ни могло поставити будући да се у српској фонологији артикулација [ije] по правилу остварује као двосложна, а никако као троглас или двоглас са глајдом у оквиру једног слога.

Поред свих ових питања која се тичу материјалног својства људског говора и на која артикулациона фонетика може да пружи некакве одговоре, постоје и она сасвим особена и врло танана, везана за говорникову и/ли слушаочеву личну перцепцију гласовног низа, перцепцију која не мора нужно бити истоветна у свим комуникативним ситуацијама, чак и када је реч о идентичним гласовним импулсима (стимулусима).

Ова потоња питања задиру, у ширем смислу, у односе који се успостављају између живих организама и њиховог физичког окружења и којима се бави посебна наука - биофизика. У ужем смислу, будући да се у нашем случају ради о понашању чула и нервног система под дејством физичких стимулуса, наш предмет интересовања припада дисциплини познатој под именом психофизика, а у оквиру те дисциплине, посебном анализом реакције људског слушног механизма на различите акустичке стимулусе бави се психоакустика. Управо у домену психоакустике јесу истраживања субјективних доживљаја неког акустичког стимулуса, односно перцепције.

Нема једнозначне кореспонденције између физичких параметара стимулуса и перцептивног одговора субјекта што значи да су и психоакустичке методе одређивања ових релација врло осетљиве. Код питања перцепције важно је споменути и праг чујности, односно нулти или референтни ниво слушања у аудиометрији, који за различите фреквенције има различиту вредност у 
децибелима (dB): за фреквенцију од $125 \mathrm{~Hz}$ праг чујности износи $45 \mathrm{~dB}$, за ону од $250 \mathrm{~Hz}-25,5 \mathrm{~dB}$, за $1000 \mathrm{~Hz}-7 \mathrm{~dB}$, за $2000 \mathrm{~Hz}-9 \mathrm{~dB}$, за $3000 \mathrm{~Hz}-10 \mathrm{~dB}$. Горњи праг чујности креће се у опсегу између $120 \mathrm{~dB}$ и $140 \mathrm{~dB}$.

Људско ухо у стању је да перципира звукове у опсегу од $20 \mathrm{~Hz}$ до $20000 \mathrm{~Hz}$, док се стимулуси испод и изнад тих вредности могу осетити као промена звучног притиска, али не и као звук.

У психоакустици је изузетно важан и ефекат временске интеграиије. Наиме, код психоакустичког мерења стимулус се субјектима пушта у одређеном временском интервалу. Ако је тај интервал дужи од једне секунде, може се сматрати бесконачним, јер са аспекта перцепције једна је секунда довољна да се сви психоакустички утисци о датом стимулусу перцептивно интегришу. Дуже излагање стимулусу не доноси додатне информације. Ако је, међутим, стимулус краћи од 10мс, тада се он перципира као транзициони или импулсни сигнал.

Тон се као стимулус сложене хармонијске структуре перципира на основу своје основне фреквенције (тоналитета). За тонове испод $1000 \mathrm{~Hz}$, за перцепцију тоналитета неопходно је трајање стимулуса од неколико периода. Временски интервал трајања стимулуса до перцепције његовог тоналитета јесте праг тоналитета. Експерименти су показали да праг тоналитета опада са 60 милисекунди за тон од $50 \mathrm{~Hz}$, до око 15 милисекунди за тон од 500 $\mathrm{Hz}$. За тонове преко $1000 \mathrm{~Hz}$ праг тоналитета је приближно константан на нивоу од око 10 милисекунди.

Уво заправо ради као детектор енергије - праг чујности је повезан са одређеним трајањем. Уво интегрише енергију у оквиру временског интервала од око 200 мс, па се цео тај ефекат назива ефектом временске интеграције. (Јовичић 1999: 231-237) 


\section{Акустичка природа гласова / j/ и /i/}

Глас /j/ је пунозвучан консонант (сонант) и по својим статистичким особинама личи на вокал /i/. 3бог тога се у класификацији фонема назива полувокалом.

На почетку речи увек је назначена његова фрикативна акустичка структура, која ишчезава у финалном и међувокалском положају у којем добија особине полувокала, односно глајда.

Вредности прва три форманта гласа /j/, према мерењима више истраживача, креће се у опсегу приказаном у табели 1 .

\begin{tabular}{|l|c|c|c|}
\hline & F1 & F2 & F3 \\
\hline Сонант $/ \mathrm{j} /$ & $350-400$ & $1800-2300$ & $2800-3200$ \\
\hline
\end{tabular}

Табела 1 - Вредности првог, другог и трећег форманта сонанта /j/ (Ако кажемо да је то консонант, хоће ли му „бити много” да буде и „сонант”?)

Слободан Т. Јовичић наводи следеће:

У акустичкој структури фонема /j/ изражена су четири полуформантна концентрата акустичке енергије, први између 100 и $400 \mathrm{~Hz}$, други око 2500, трећи изнад 3000 и четврти изнад 4000. Прва три концентрата по спектралним положајима одговарају положајима форманата вокала и, што потврђује полазну констатацију о великој сличности сонанта $j$ и вокала $u$. (Јовичић 1999: 67)

За разлику од /j/, вокал / i / има јасно изражене форманте чија се фреквенција креће у опсезима наведеним у табели $2^{2}$.

2 Напомињемо да су у табели дате средње вредности, при чему је у корпусу Д. Петровића и С. Гудурић било више испитаника женског пола, те је и просечна вредност у херцима нешто виша. 


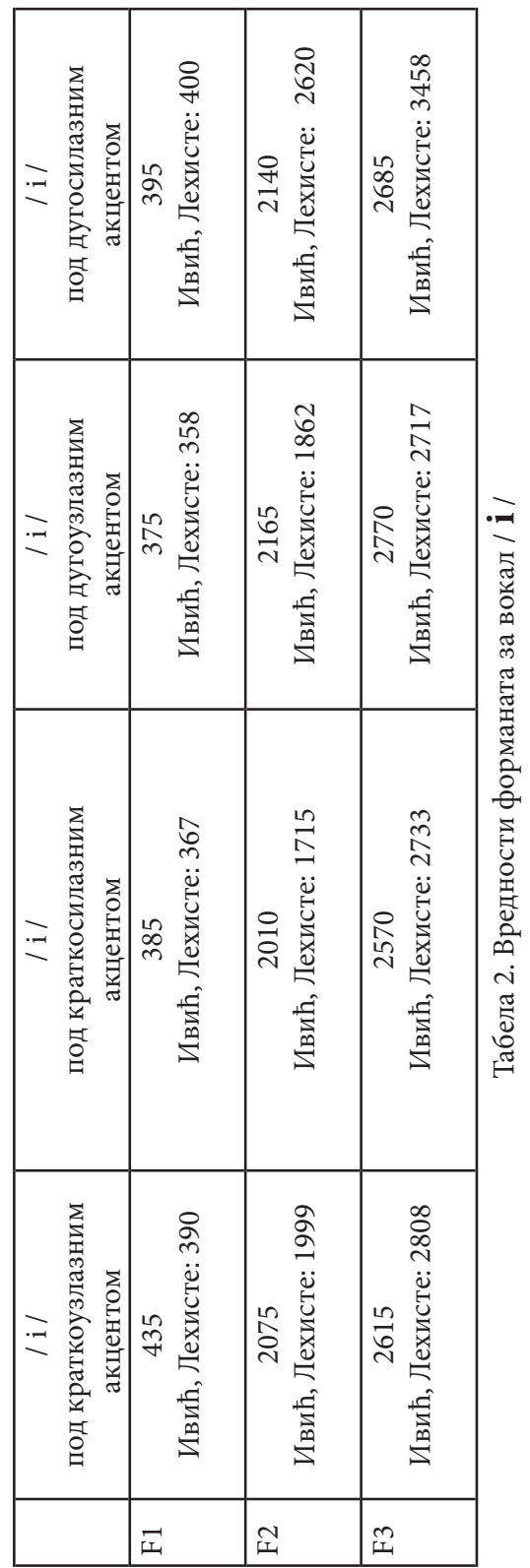


И. Шкарић наводи следеће вредности форманата за вокал / i / : $F_{1}=360 \mathrm{~Hz}, \mathrm{~F}_{2}=2200 \mathrm{~Hz}$, a F$_{3}=2850 \mathrm{~Hz}$.

Нас су у овом раду интересовале реализације налик на оне приказане на слици 1.

На сл. 1 присутне су две реализације гласа ј унутар речи, прва иза јасно артикулисаног самогласника и, а друга иза билабијалног звучног оклузива иза којег следе кратка артикулација / і / и транзиција према /e/. На спектрограму 1.a јасна је формантска структура гласа / i / иза оклузива, док осенчени део, такође формантске структуре, који представља прелаз од / і / ка /e/, траје веома кратко и ако се снимак преслуша, даје акустички утисак /j/. На сл. 1.6, непосредно иза оклузива, такође је видљива формантска структура гласа / i /, али врло кратка, која затим прелази у /j/ које је засенчено и представља сегмент прелаза на артикулацију /е/. Преслушавањем иницијалног дела (незасенченог) гласа са одсечка [bje] добија се јасан акустички утисак изговореног вокала [i], који траје све до места на коме долази до пада другог и трећег форманта при преласку на артикулацију наредног вокала. Уколико се упореде висина $\mathrm{F}_{1}$ и $\mathrm{F}_{2}$ за вокал/и/ са слике 1.а и висина истих форманата за иницијални део артикулације која следи иза оклузива са сл. 1.б, јасно је да је реч о истоветним артикулацијама чији се други формант пење до висине од преко $2000 \mathrm{~Hz}$, а што је фреквенција у којој се формира $\mathrm{F}_{2}$ затвореног предњег вокала $/ u /$. 


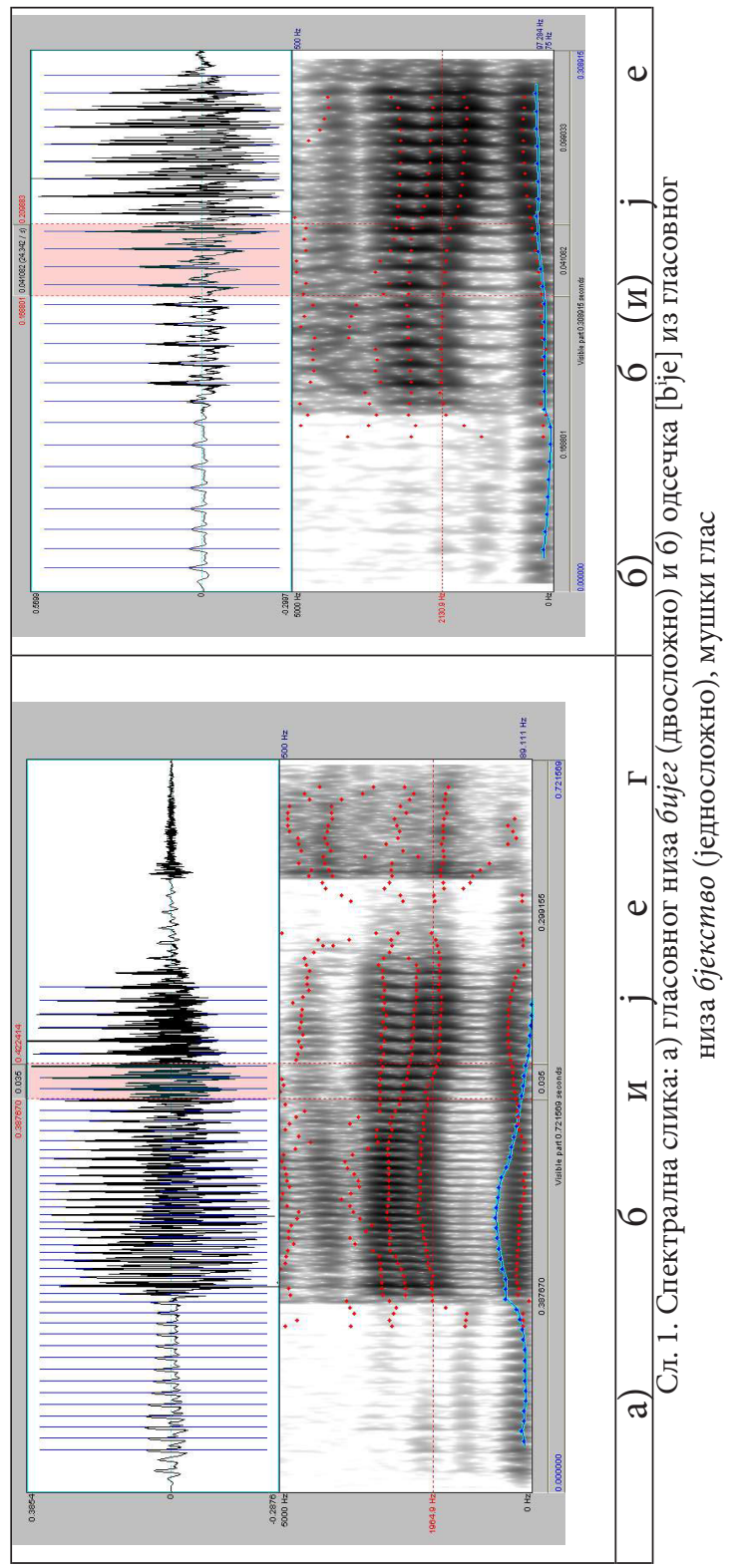




\section{4. Анализа корпуса драгачевског говора}

Звучни материјал који смо анализирали обухвата два аудио снимка, један дужине 2 сата 14 минута и 11 секунди, а други 1 сат 52 минута и 46 секунди, на којима је забележен разговор са старијом особом женског пола, као и снимак Милоја Стевановића, једног од аутора Речника драгачевског говора, у трајању од 1 минута и 2 секунде. Снимци су обрађени у програму ПРААТ.

Нас у овом истраживању нису занимали фреквенцијски опсези појединих форманата гласова које смо посматрали већ њихов распоред који указује на присуство односно одсуство артикулације одређеног типа гласа и то искључиво у наглашеном слогу. У добијеним спектрограмима тражили смо спектралне слике карактеристичне за гласове /i/, /j/ и /e/ (искључиво када се налази испред $/ \mathrm{j} /$ ), при чему смо мерили трајање сваке од ове три артикулације. Будући да се појединачни гласови у гласовним низовима не слажу један до другог већ прелазе један у други, да бисмо поткрепили своју сегментацију приложили смо табеларни приказ кретања фреквенцијске вредности појединих форманата посматраних гласова. Сегментација је вршена на основу осцилограма, спектрограма и пратећих вредности форманата, а додатна провера вршена је преслушавањем сваког одсечка. Могућност варијације у трајању гласа износи 0,006 секунди, што на слици представља минимални временски интервал сегментације. На нивоу перцепције, дужина трајања артикулације од 0,006 секунди није довољна да би се она јасно дискриминисала у односу на неку другу.

Од укупно 56 спектрограма направљених у сврху нашег истраживања, у овом раду приказујемо њих 10 који у потпуности одсликавају укупно стање у корпусу 
везаном за посматрану проблематику (изговор [je] или [ije]).

Напомињемо да су на аудио снимцима биле присутне и екавске артикулације, којима се у овом раду нисмо бавили.

Обратимо пажњу на наредне две спектралне слике чије су артикулације сарадници на Речнику различито перципирали: први као бјело (сл.2) и бијело (сл.3), а други је у оба случаја чуо артикулацију бијело. Напомињемо да је други аутор фонолог и да има врло истанчано ухо те да чује и препознаје артикулације које просечном изворном говорнику српског језика, па самим тим и драгачевског говора, измичу. 


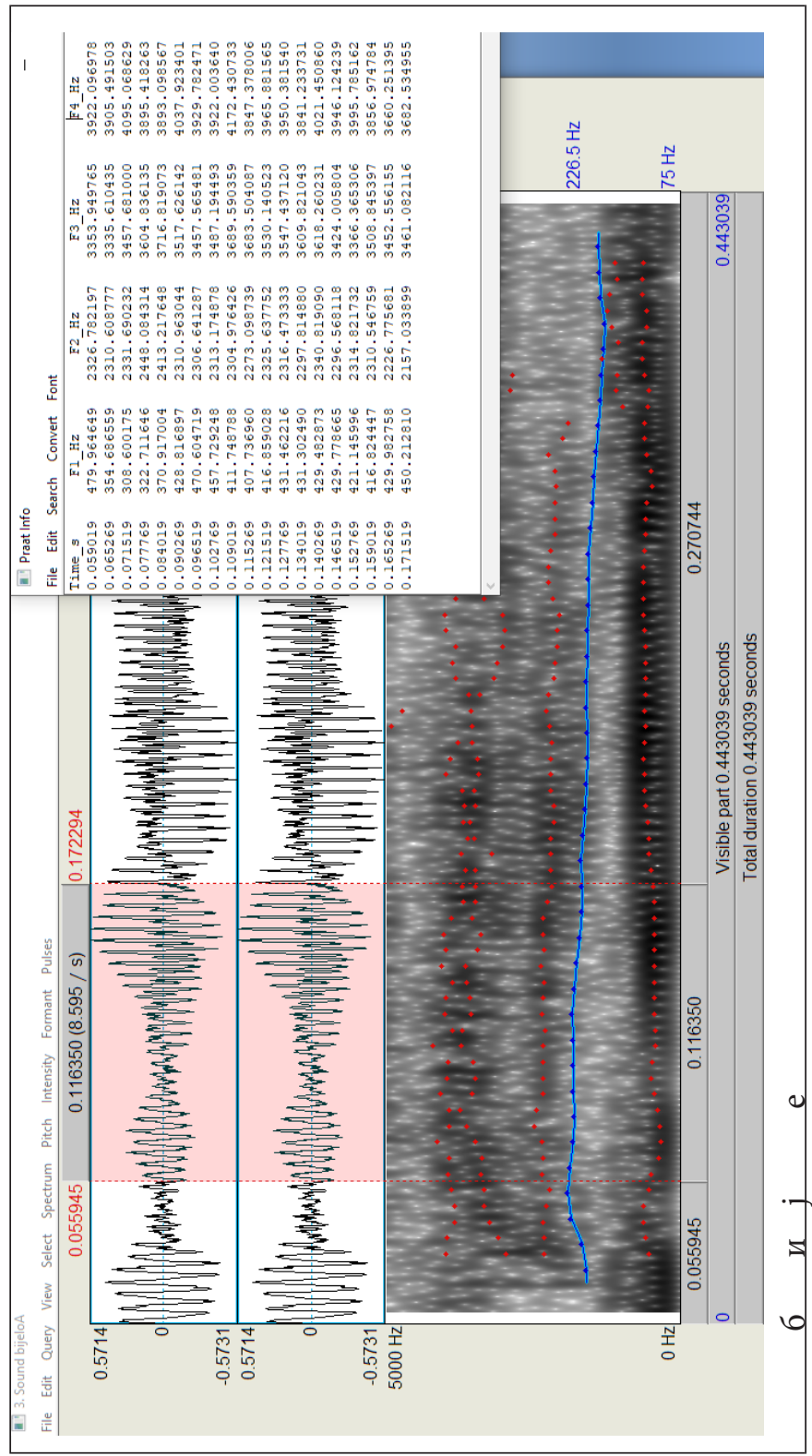




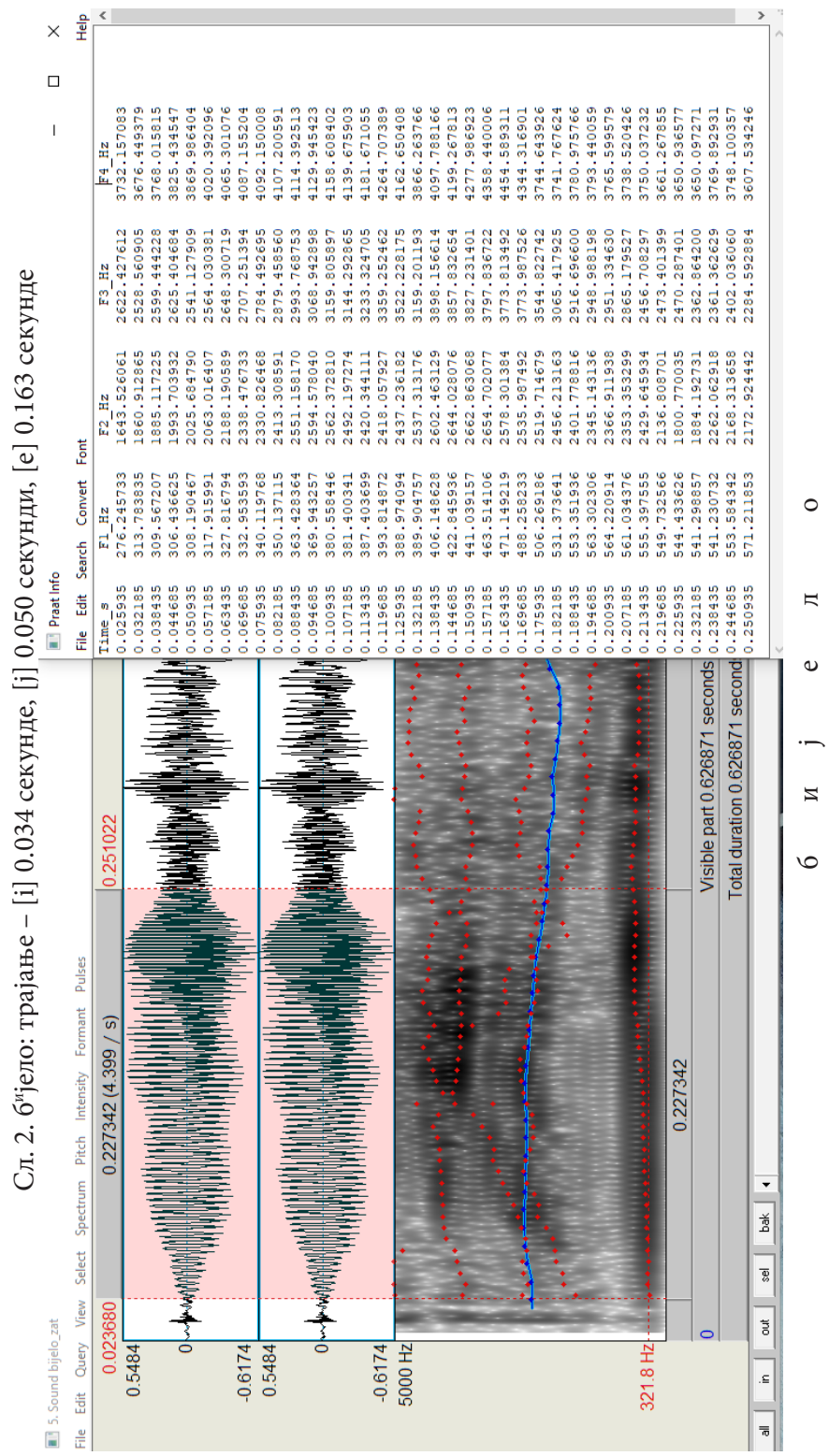


Сл. 3. бијело: трајање - [i] 0.086 секунде, [j] 0.049 секунде, [е] 0.085 секунде

На обе спектралне слике јасно је уочљива артикулација гласа [i], али његово је трајање на слици 3. више него дупло дуже од онога са слике 2, док је трајање [j] уједначено што не чуди будући да је у питању прелазна артикулација (глајд). Трајање гласа [i] од свега 34 милисекунде није било довољно да га први аутор чује, али га је истанчано ухо фонолога, другог аутора, сасвим добро „ухватило”. Што се тиче гласа [е], разлика у његовом трајању (163 милисекунде / 85 милисекунди) потпуно је ирелевантна будући да је 85 милисекунди више него довољно да се глас јасно перципира, а свако његово даље продужење доноси искључиво супрасегменталну, а не сегменталну информацију.

За даља истраживања оваквих артикулација биће свакако занимљива и чињеница да оба посматрана слога имају приближно исто трајање, онај са слике 2. траје 247 милисекунди, а онај са слике 3. - 220 милисекунди.

Наредне све слике (сл. 4 и сл. 5) доносе спектрограме речи бријегу и тијеже, у којима су оба аутора Речника јасно чула артикулацију [i] испред [j]. И овде се, међутим, појавила разлика у личном језичком осећају: један је обе речи перципирао као тросложне, а други је гласовни низ лијеже перципирао као двосложан. 


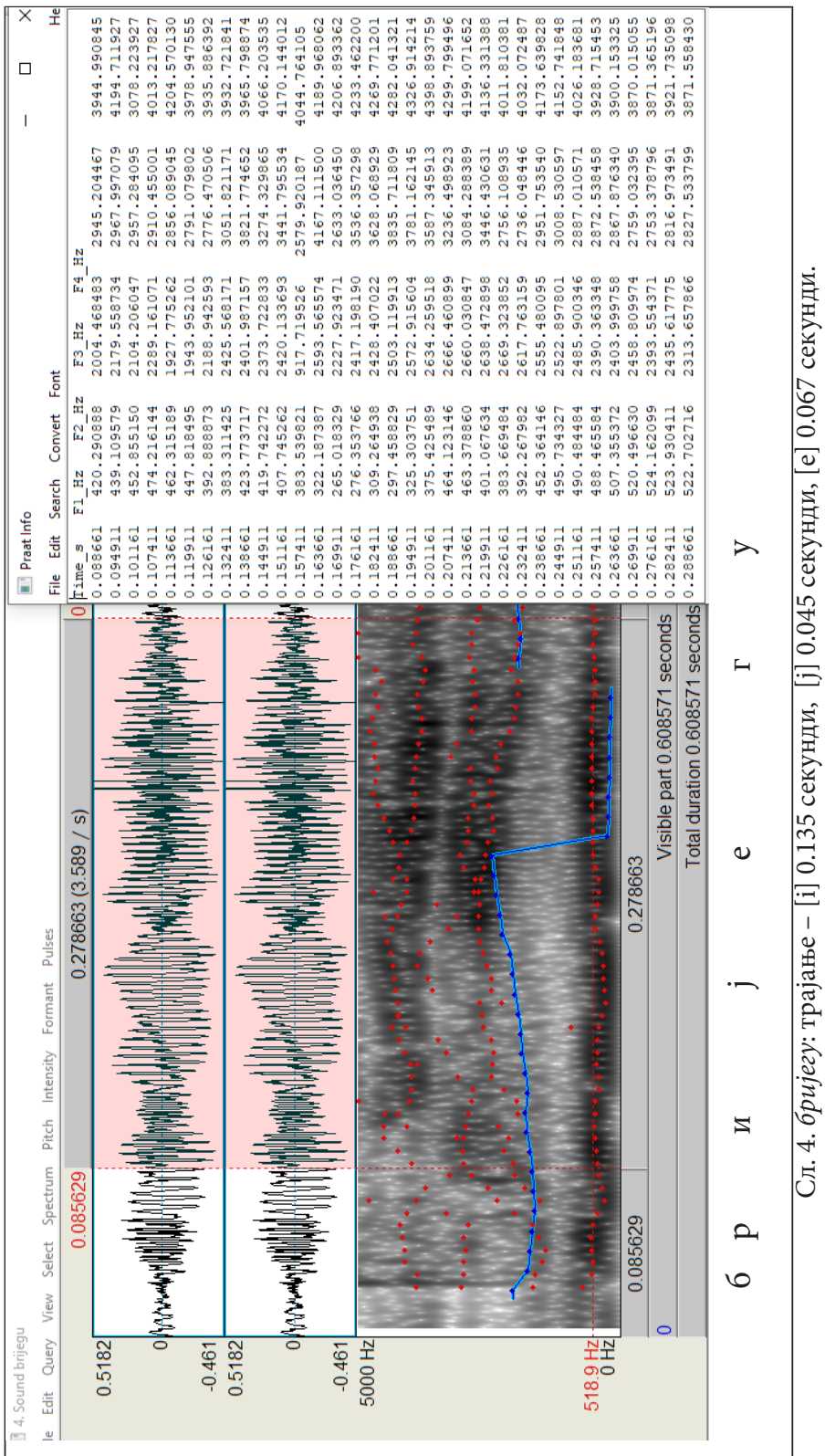




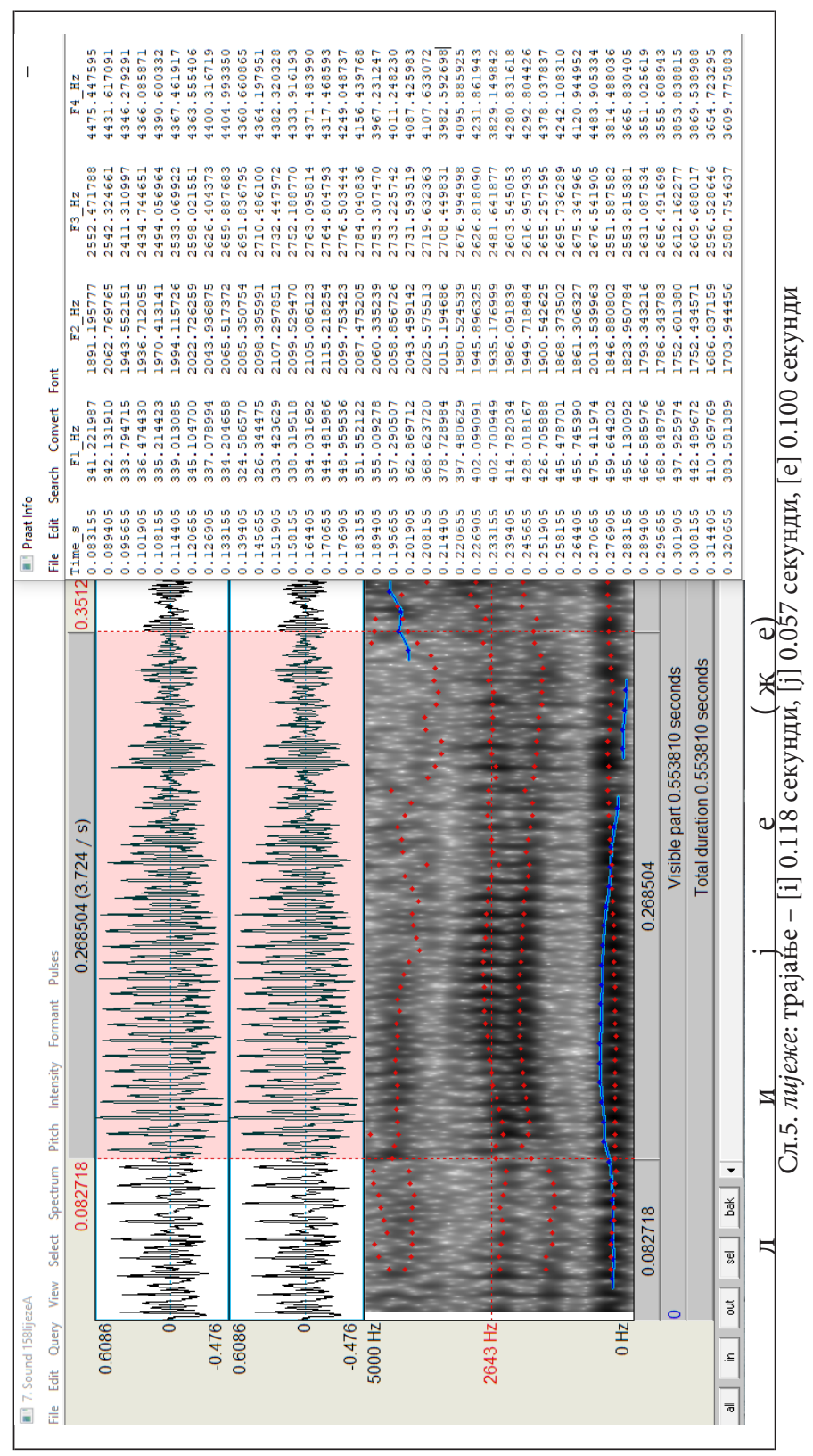


Ако упоредимо трајање појединачних гласова, установићемо да су они довољно трајали да би их сваки говорник јасно перципирао. Разлика се, међутим, појавила у перцепцији супрасегменталних обележја двају гласовних низова што је довело до различитог доживљаја силабичког састава речи бријегу и лијеже код два аутора Речника.

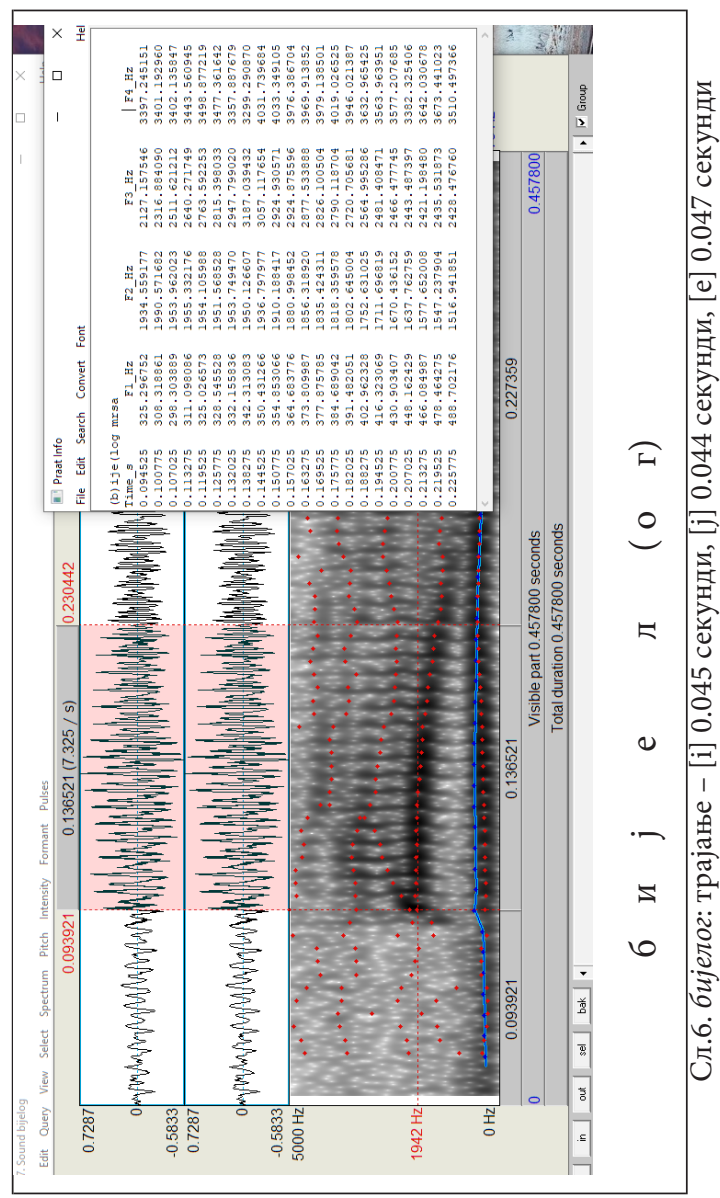


И на сл. 6. кретање $\mathrm{F}_{0}$ благо је порасло на првом вокалу ([i]) да би при емисији наредних гласова задржало скоро равну линију. Трајање вокала [i] и [e], као и транцизије међу њима врло је уједначено, при чему један од аутора Речника није чуо артикулацију [i] већ је гласовни низ перципирао као двосложну лексему бје-лог.

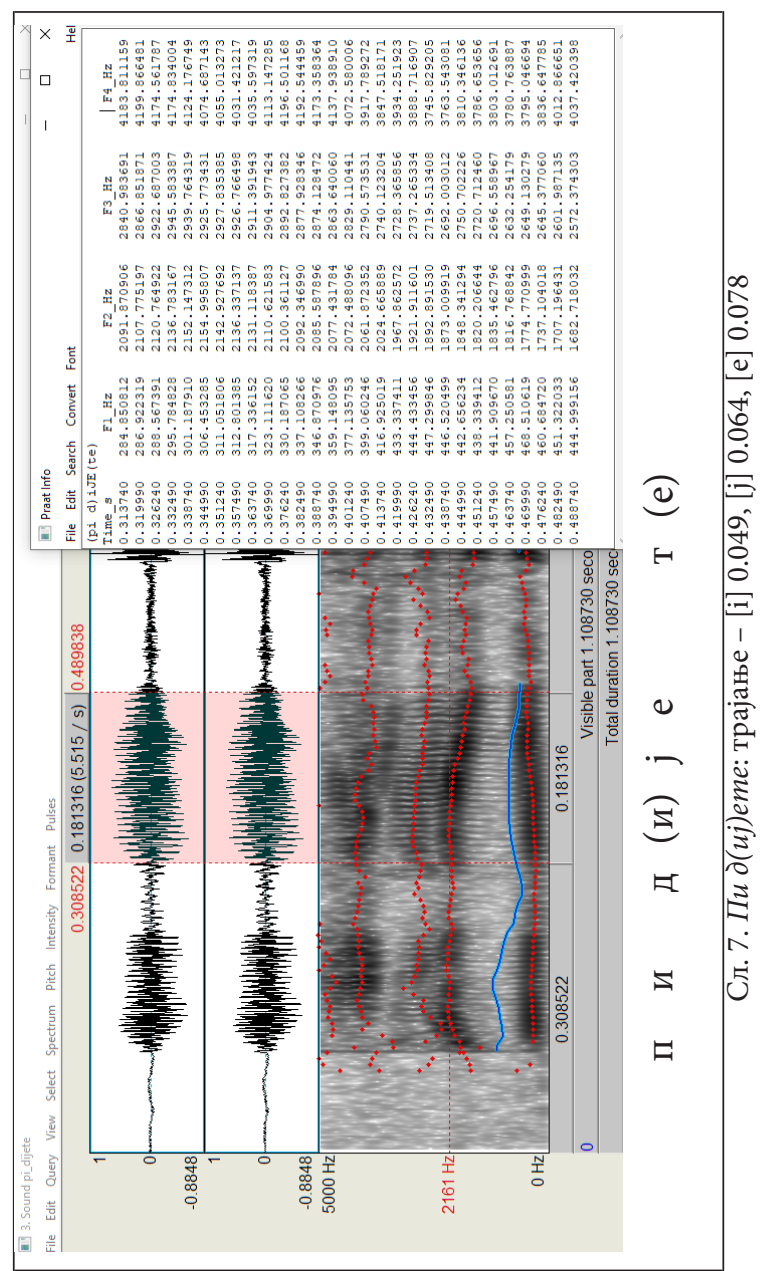




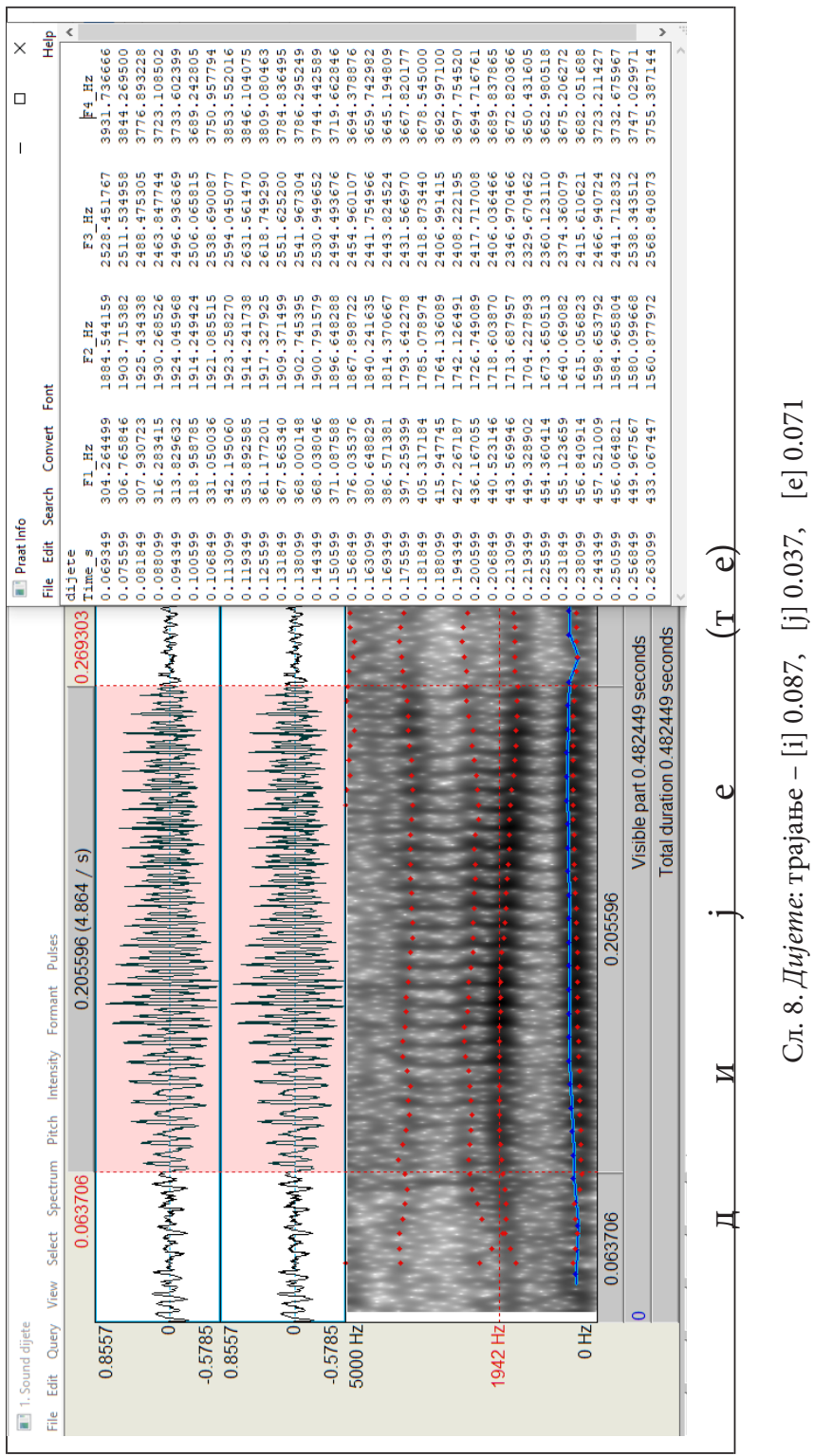


На сликама 7. и 8. приказани су спектрограми лексеме дијете изговорене на два начина: на сл. 7. артикулација [i] је краћа и од транзиционог гласа [j] и од [e] које му следи, тако да је за једног од испитаника она заправо непостојећа, односно, он ову лексему исписује као dјете и чује је као двосложну. На сл. 8. иста лексема изговорена је са скоро двоструко дужим [i], али и скоро двоструко краћим глајдом, док је трајање [e] у оба случаја слично. Оба испитаника су у овом случају лексему исписивала на исти начин - дujeme и доживљавали су је као тросложну. 


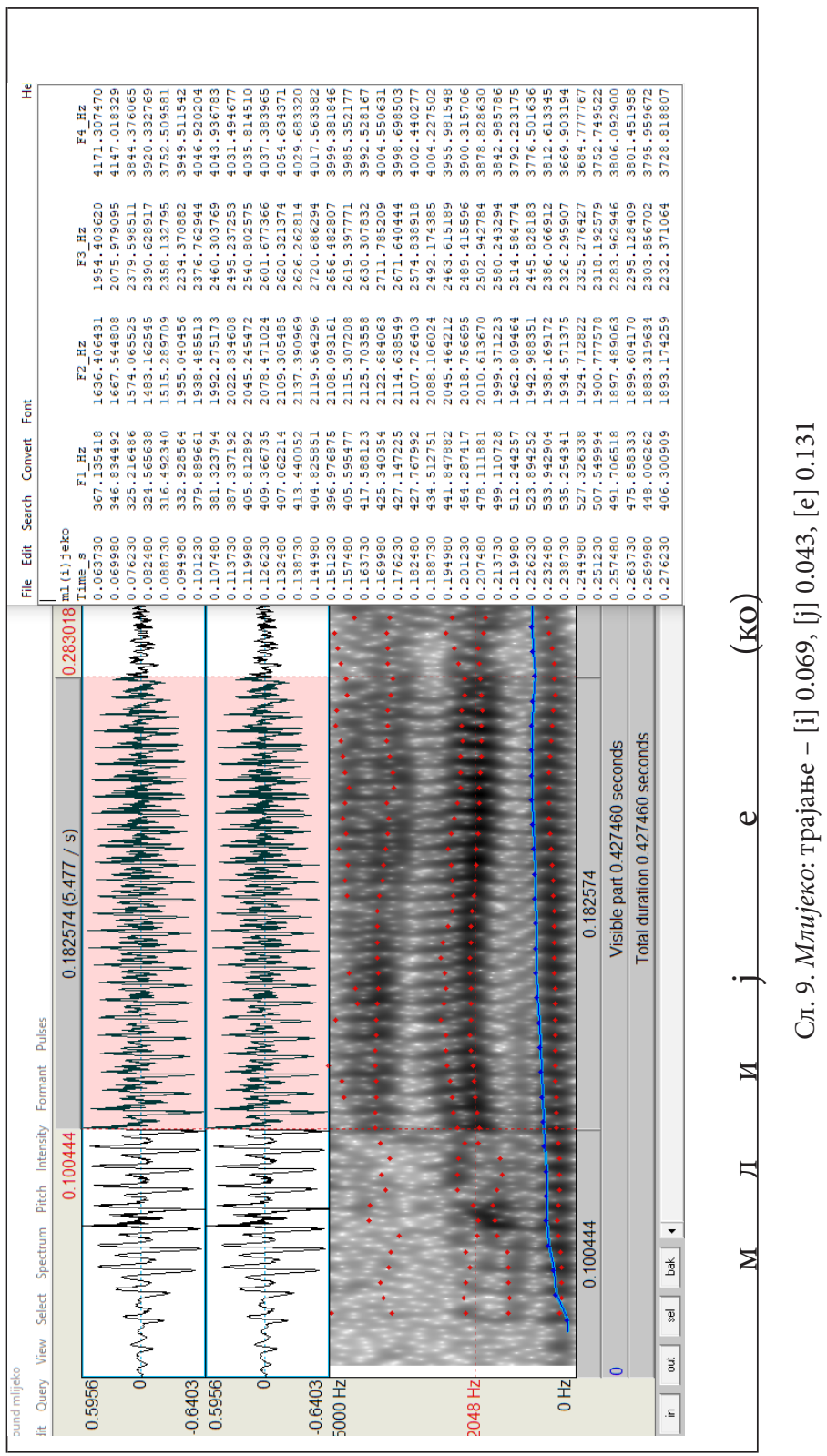


И лексему приказану на сл. 9. два испитаника су перципирала на различите начине - један је јасно чуо артикулацију [i], док је други тврдио да тога гласа нема, односно да реч гласи млјеко. Спектрограм јасно показује присуство вокала /i/ чије је трајање чак 69 милисекунди. Укупна дужина те артикулације и глајда приближава се дужини трајања гласа [e], од које је краћа тек неких 20-ак милисекунди.

Присуство артикулације [i] могло се унапред претпоставити будући да је изостало јотовање - да је $\pi$ дошло у непосредан контакт са $j$, извршило би се јотовање те би његов резултат био гласовни низ мљеко. Чињеница је, међутим, да то [i] није довољно дуго трајало да би га један од испитаника јасно перципирао, поготово с обзиром на чињеницу да у његовом језичком осећају постоји и облик млијеко у којем је трајање артикулације [i] дупло дуже неко у облику млијеко. 


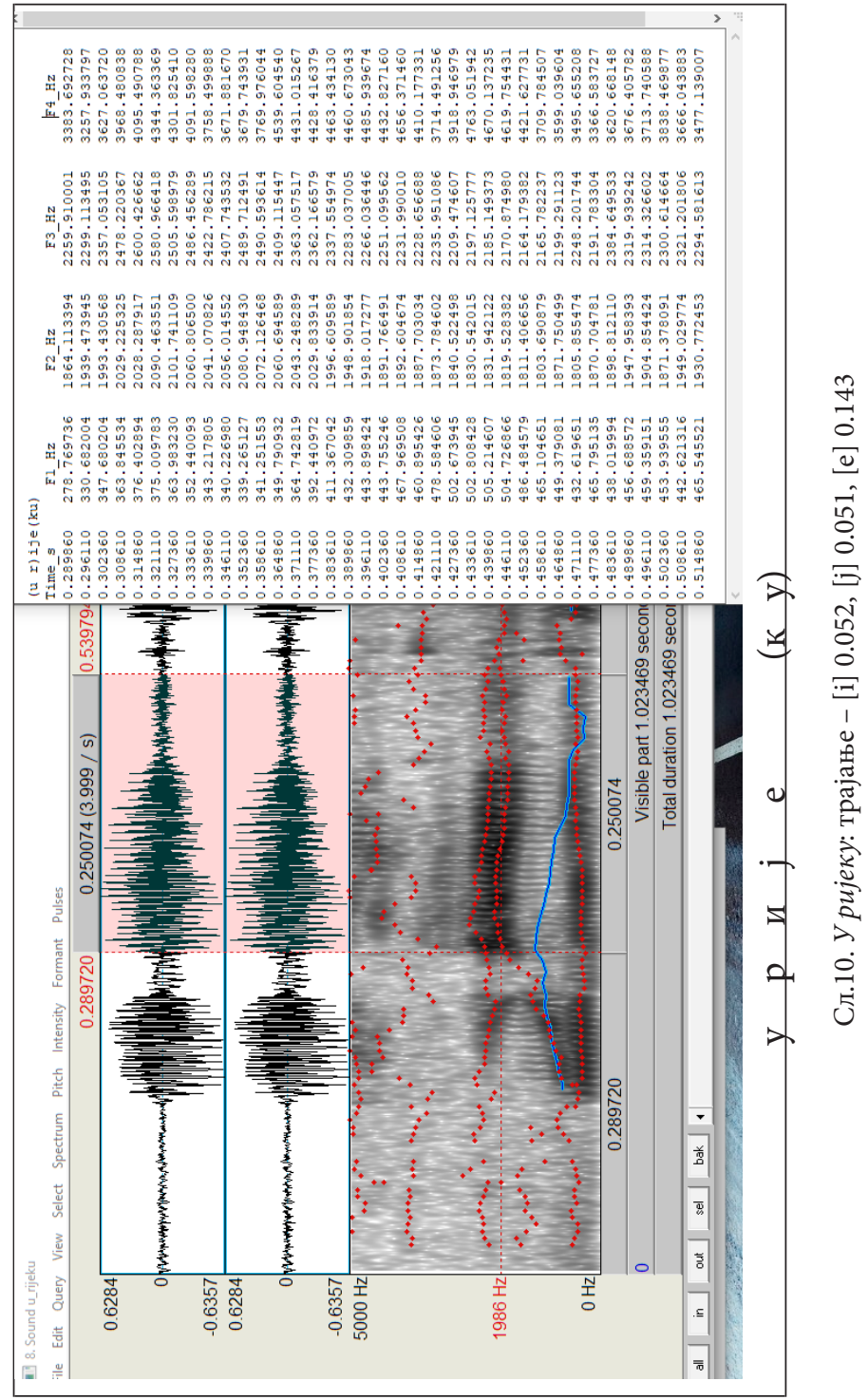


Испитаници су различито перципирали и гласовни низ у ријеку - један је чуо четворосложни, а други тросложни низ - $y$ рјекуз. Спектрограм је непобитно забележио присуство артикулације [i] која је трајала око 50 милисекунди, колико је забележено и трајање глајда, односно транзиционог гласа [j]. Дужина артикулације [e] је у истом низу једнака приближно троструком трајању сваке од две претходне артикулације.

3 У овом примеру посматрали смо цео гласовни низ у ријеку будући да је испитаница акцентовала предлог $у$ те се секвенца [ije] нашла иза акцента. 


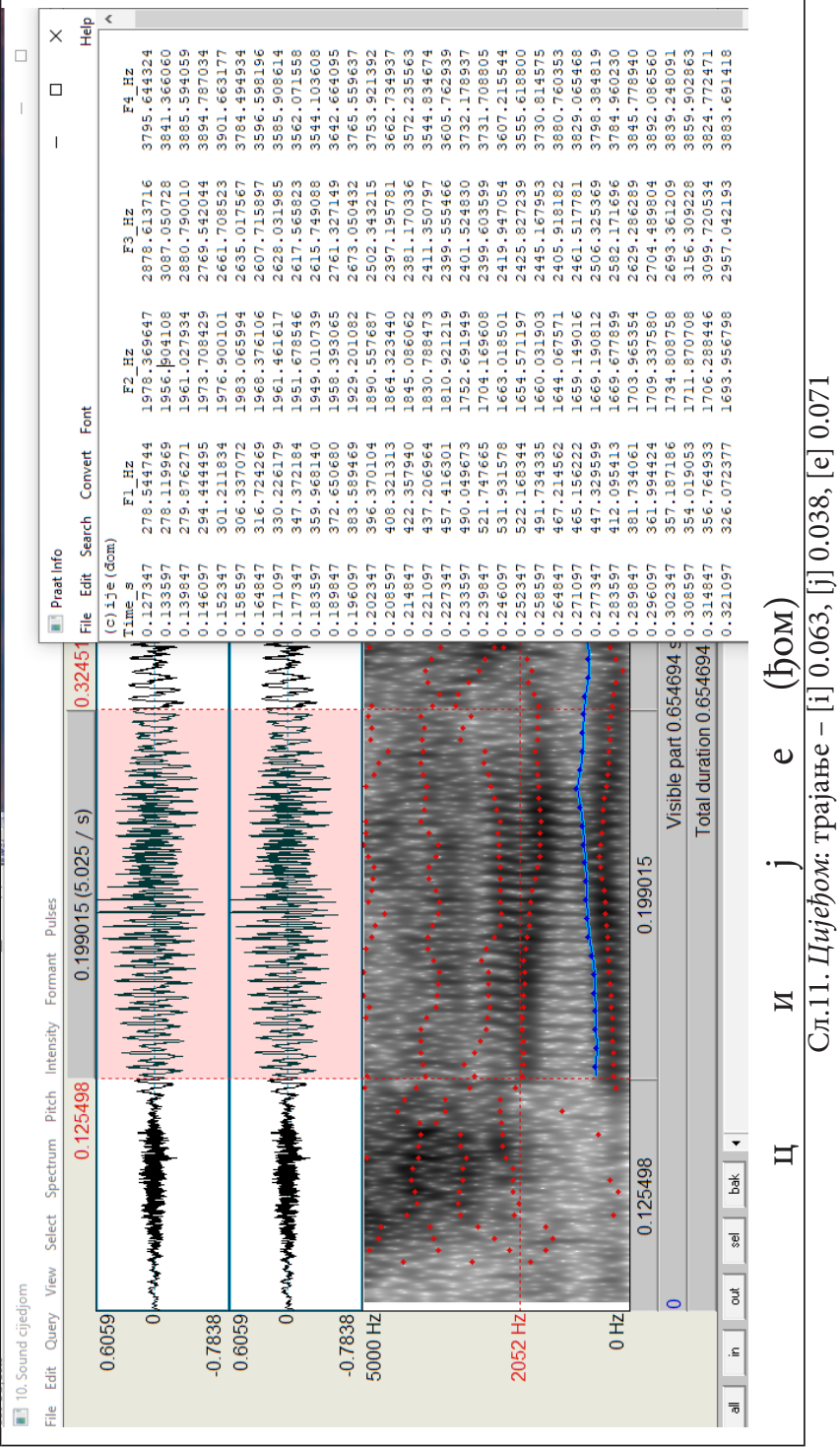


И слика 11. приказује гласовни низ који су испитаници различито перципирали, док је један чуо облик цијеђом, други је исти низ доследно бележио као ијеђом. Иако је дужина гласова [i] и [e] приближно иста, један од испитаника није успевао да чује [i], али је сасвим исправно чуо [е]. При томе, ниједан од испитаника није доводио у питање присуство [j], иако његова дужина једва прелази половину трајања претходна два гласа.

\section{5. Уместо закључка}

Преслушавајући добијени звучни материјал, могли смо да закључимо да се у корпусу, на месту дугог јата, јављају три могуће артикулације: [e], [je] и [ije]. Дакле, одговор на питање да ли су данашњи Драгачевцу екавци, јекавци или ијекавци, нажалост, није једноставан будући да су у свим звучним записима јасно потврђена сва три типа изговора.

Позвана да пресуди у спору који се односио на присуство или одсуство арикулације [i] испред [je] у једном броју случајева, акустичка фонетика је у потпуности испунила свој задатак: на свим спектралним сликама које су наши испитаници сматрали „проблематичним” било је евидентно присуство вокала [i] испред [j], при чему је његово трајање варирало од 0.034 до чак 0.135 секунди. У случајевима када је трајање [i] било испод 70 милисекунди, један од испитаника није успевао да га перципира и доследно је бележио гласовни низ [je] уместо [ije].

У највећем броју случајева нема слоговног предвајања између [i] и [je], што значи да су овакве артикулационе реализације махом једносложне. 
Иако су спектралне слике потврдиле став фонолога о присуству артикулације [i] испред [je] у свим посматраним случајевима, остало је отворено питање фонолошког исписа дела материјала у којем је трајање [i] испод 70 милисекунди, односно, који глас ставити у експонент, а који означити као основни:

\section{брu'er, du'eme}

или

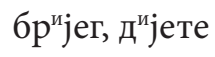

или

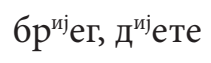

при чему последња два исписа треба да упуте на једносложни изговор.

Ова кратка акустичка анализа показала је да преслушани узорак није довољан за извођење општих валидних закључака о томе ком изговорном типу припадају данашњи Драгачевци. Приликом теренских истраживања, не могу се занемарити утицаји масовних медија који су данас присутни у сваком драгачевском дому и који младим генерацијама намећу неке нове изговорне обрасце. С обзиром на овакво стање, ваљало би акустички обрадити старији материјал те га упоредити са новијим, сакупљеним на истом терену.

У сваком случају, за наше дијалектологе на подручју Драгачева још увек има доста посла.

\section{ЛИТЕРАТУРА}

Ђукановић 1995: Петар Ђукановић, Говор Драгачева. Српски дијалектолошки зборник. Београд, XLI, 1-240. 
Ердељановић 1902: Јован Ердељановић, Доюе Драгачево : Антропогеографска проучаваға. - Српски етнографски зборник, IV : Насеља српских земаља. Београд (СКА), Књига I, III + 1-250.

Јовановић 1908: Коста Јовановић, Горне Драгачево : Антропогеограбска проматрана. Српски етнографски зборник, XI : Насеља српских земаља. Београд (СКА), Књига $\mathrm{V}, 311-426$.

Челиковић 2010: Борисав Челиковић [Прир.], Драгачево : Насеља, порекло становништва, обичаји. Београд (Службени гласник : САНУ), 1-432.

Стевановић 2012: Грешни Милоје (Милоје Стевановић), Казивана. Ниш.

Стевановић 2017: Милоје Стевановић, Спомени, дужи од живота. Београд.

Маринковић Р, Маринковић 3, Стевановић М: Радован Маринковић, Зоран Маринковић, Момчило Стевановић, Камени памћеници Горачића. Гуча.

Николић Р. 2018: Радојко Николић, Камена книга предака. Чачак.

Николић 2007: Славомир Славо Николић, Писано под шајкачом. Чачак.

Стојић 1986: Ника Никола Стојић, Драгачевски епитафи. Чачак.

Цвијић 1902: Ј. Цвијић (ур.), Насеља српских земаља, књ.1 Српски етнограбски зборник (књ.4). Београд: САНУ. 
Snežana U. Gudurić

Dragoljub Petrović

\section{RÉFLEXES DU YAT LONG DANS LE PARLER DE DRAGAČEVO \\ Analyse acoustique}

\section{Résumé}

Le texte porte sur les réflexes du yat long dans le parler de Dragačevo. Un des auteurs du Dictionnaire du parler de Dragačevo a contesté les résultats de recherches de P.Đukanović qui avait trouvé la prononciation dissylabique du yat long dans les mots вијек, бријег, диंете, млијеко, en prétendant que ces mots sont tous monosyllabiques. Lanalyse acoustique du corpus a démontré la présence de l'articulation [i] devant [je], mais sa durée variait entre 34 et 118 millisecondes. Un des auteurs du Dictionnaire ne percevait pas les articulations dont la durée était moindre à 70 milisecondes et considérait ces articulations comme monosyllabiques. Par contre, chaque fois que la durée de [i] dépassait les 70 milisecondes, les deux auteurs du Dictionnaire le persevaient sans problème, nétant tout de même pas toujours d'accord sur la structure syllabique des mots en question.

Pour que la notation phonologique des entrées dans le Dictionnaire soit la plus fidèle possible à la prononciation des sujets parlants de Dragačevo, nous proposons quelques variantes: бpujez, dujeme pour des articulations disyllabiques, et бpujez, дujeme ou брujez, dujeme pour des articulations monosyllabiques.

Mots clés : dialectologie, analyse acoustique, réflexes du yat, parler de Dragačevo. 